University of Nebraska - Lincoln

DigitalCommons@University of Nebraska - Lincoln

2013

\title{
A 7-plex microbead-based immunoassay for serotyping Shiga toxin-producing Escherichia coli
}

Laurie M. Clotilde

U.S. Food and Drug Administration San Francisco District Laboratory

Clay Bernard IV

U.S. Department of Agriculture

Alexandra Salvador

U.S. Department of Agriculture

Andrew Lin

U.S. Food and Drug Administration San Francisco District Laboratory

Carol R. Lauzon

California State University

See next page for additional authors

Follow this and additional works at: https://digitalcommons.unl.edu/publichealthresources

Clotilde, Laurie M.; Bernard, Clay IV; Salvador, Alexandra; Lin, Andrew; Lauzon, Carol R.; Muldoon, Mark; Xu, Yichun; Lindpaintner, Klaus; and Carter, J. Mark, "A 7-plex microbead-based immunoassay for serotyping Shiga toxin-producing Escherichia coli" (2013). Public Health Resources. 291.

https://digitalcommons.unl.edu/publichealthresources/291

This Article is brought to you for free and open access by the Public Health Resources at DigitalCommons@University of Nebraska - Lincoln. It has been accepted for inclusion in Public Health Resources by an authorized administrator of DigitalCommons@University of Nebraska - Lincoln. 


\section{Authors}

Laurie M. Clotilde, Clay Bernard IV, Alexandra Salvador, Andrew Lin, Carol R. Lauzon, Mark Muldoon, Yichun Xu, Klaus Lindpaintner, and J. Mark Carter 


\title{
A 7-plex microbead-based immunoassay for serotyping Shiga toxin-producing Escherichia coli
}

\author{
Laurie M. Clotilde a , Clay Bernard IV ${ }^{\mathrm{b}}$, Alexandra Salvador ${ }^{\mathrm{b}}$, Andrew Lin ${ }^{\mathrm{a}}$, Carol R. Lauzon ${ }^{\mathrm{c}}$, \\ Mark Muldoon ${ }^{\mathrm{d}}$, Yichun Xu ${ }^{\mathrm{e}}$, Klaus Lindpaintner ${ }^{\mathrm{e}}$, J. Mark Carter ${ }^{\mathrm{b}, *}$ \\ a U.S. Food and Drug Administration San Francisco District Laboratory, 1431 Harbor Bay Parkway, Alameda, CA 94502, United States \\ b U.S. Department of Agriculture, Agricultural Research Services, 800 Buchanan St., Albany, CA 94710, United States \\ c California State University, East Bay, Department of Biological Sciences, 25800 Carlos Bee Blvd., Hayward, CA 94542, United States \\ d Romer Labs Technology, Inc., 130 Sandy Drive, Newark, DE 19713, United States \\ e Strategic Diagnostics Inc. (SDIX), 111 Pencader Dr., Newark, DE 19702, United States
}

\section{A R T I C L E I N F O}

\section{Article history:}

Received 9 October 2012

Received in revised form 30 November 2012

Accepted 30 November 2012

Available online 7 December 2012

\section{Keywords:}

Escherichia coli

Serotyping

Multiplex

Immunoassay

Antisera

Luminex

\begin{abstract}
A B S T R A C T
Serotyping of Shiga toxin-producing Escherichia coli (STEC) has been contingent upon the availability of antisera. Here we describe a 7-plex microbead-based immunoassay to simultaneously serotype seven STECs (i.e., belonging to serogroups $026,045,0103,0111,0121,0145$, and 0157 ) by the Luminex XMAP ${ }^{8}$ technology. This technology presents many advantages: Its multiplexed format (up to 100 analytes) saves time, reagents, and test sample, and many regulatory agencies currently utilize this platform for other assays. In this study, a total of seventy-nine STEC strains belonging to the 7 different serogroups of interest were tested. These strains had been previously serotyped and their serogroup was confirmed by PCR. Except for one strain belonging to the 0111 serogroup, nearly all strains (i.e., 98.7\%; 78/79) were correctly identified on the Bio-Plex 100 instrument in less than $4 \mathrm{~h}$. This newly developed microbead-based immunoassay could be extended to include other STEC serogroups, virulence factors, and/or bacterial species.
\end{abstract}

Published by Elsevier B.V.

\section{Introduction}

Since the active surveillance of non-0157 STEC was implemented in the United States in 2001 (CDC, 2012), there has been an increase in number of reported cases of serotypes other than 0157 mostly in part due to enhanced testing for the presence of Shiga toxin (Stx) in outbreak related strains (Hurd, 2007). Currently non-0157 infections account for approximately $50 \%$ of all confirmed STEC cases in Europe and in the United States they out number reported 0157 cases (Bosilevac and Koohmaraie, 2011). Yet, the most virulent serotype commonly isolated in outbreaks in North America is Escherichia coli 0157:H7, and is associated with bloody diarrhea, hemorrhagic colitis (HC), hemorrhagic uremic syndrome (HUS), and thrombotic thrombocytopenic purpura (Brooks et al., 2005; Willshaw et al., 2000). However, the last 10 years have produced an increasing number of outbreaks in the United States attributed to non-0157 STEC which can elicit infections and diseases similar to E. coli 0157:H7 (Anonymous, 1995; Banatvala et al., 1996; Tarr et al., 1996; Fey et al., 2000; Brooks et al., 2004). It is estimated

\footnotetext{
* Corresponding author at: 800 Buchanan St., Albany, CA 94710, United States. Tel.: + 1 510559 6053; fax: + 15105596429 .

E-mail address: j.mark.carter@ars.usda.gov (J.M. Carter).
}

that 96,534 infections are caused by E. coli 0157:H7, annually in the United States while non-0157 STECs serotypes cause 168,698 infections (Scallan et al., 2011). Approximately 20-50\% of worldwide STEC infections are caused by non-0157 serotypes; incidence varies depending on geographical topology as well as climate conditions (Johnson et al., 2006; Nataro and Kaper, 1998) Cattle represent the prime reservoir of STEC strains, exhibiting a particularly high prevalence of non-0157 STEC strains (Bettelheim, 2001). The top six non-0157 STEC serogroups most commonly implicated in illnesses are 026, 0111, 0103, 0121, 045, and 0145 (Atkinson et al., 2006; Brooks et al., 2005; Gyles, 2006). STECs causes human illness by expressing at least one Shiga toxin gene (Stx) consisting of two forms; Stx1 and Stx2. Between these two isoforms, Stx2 exhibits higher virulence. Its variants are associated with an enhanced probability of HC and HUS (Beutin et al., 2008). Not all non-0157 STECs will cause human illness, therefore developing a rapid and highly sensitive method for identification of non-0157 STEC capable of pathogenesis would be of great benefit for regulatory agencies as well as in clinical medicine (Bettelheim, 2007).

We have developed a 7-plex microbead-based immunoassay to allow simultaneous serotyping of STEC strains belonging to serogroups 026 045, 0103, 0111, 0121, 0145, and 0157 by the Luminex XMAP® technology. Polyclonal antibodies that bind each bacterial serogroup were conjugated to microbeads used by the Luminex platform, thus allowing the identification of specific pathogenic bacteria. We tested the specificity 
of our 7-plex microbead-based immunoassay against a collection of 79 PCR typed E. coli strains belonging to the top 7 E. coli. Such an immunoassay presents significant advantages. The 96-well format allows high throughput, while the multiplexed format (up to 100 analytes) saves time, reagents, and test samples. Conventional serotyping methods for identification of non-0157 STECs are reliable forms of classification, but can be laborious as well as time consuming often requiring skilled technicians having access to sufficient high quality $\mathrm{H}$ antisera, which are mostly available in a few reference laboratories worldwide (Machado et al., 2000). Many affiliated Food Safety and Inspection Service (FSIS), Food and Drug Administration (FDA), and Food Emergency Response Network (FERN) laboratories currently utilize the Luminex platform for other assays, and our immunoassay would be directly transferable and could be implemented by these laboratories.

\section{Materials and methods}

\subsection{Antibodies}

The antibodies used in this study were previously described (Olsson-Allen et al., 2011; Hegde et al., 2012). These were prepared and purified by SDIX using proprietary methods. Several antibodies (goat anti-E. coli O26, 045, 0103, 0111, 0121, 0145, and 0157; rabbit anti-E. coli 026, 045, 0103, 0111, 0121, 0145, and 0157; and mouse anti-E. coli 0157) were screened against one representative strain of each serogroup by indirect then by microplate sandwich ELISA, using a checkerboard strategy to determine the optimized concentrations of both capture and detector antibodies (data not shown). Except for 045, 0145 and 0157, the capture antibodies with the highest signal to noise ratio were from goats (data not shown). The best capture antibodies for 045 and 0145 were from rabbit samples, and the ones chosen for 0157 were of murine origin. Except for the capture antibodies for 0157 which were used at a concentration of $50 \mu \mathrm{g} / \mathrm{mL}$, all antibodies were used at a concentration of $5 \mu \mathrm{g} / \mathrm{mL}$. Except for 0157, the same antibodies were used for both capture and detection. The best detection antibodies for 0157 were from goat samples. All detection antibodies were used at concentrations of $1 \mu \mathrm{g} / \mathrm{mL}$. Detector antibodies were biotinylated with the EZ-Link Sulfo-NHS-Long Chain-Biotin kit (Pierce, Rockford, IL), according to the manufacturer's instructions.

\subsection{Analytes}

E. coli strains (Table 1) were inoculated in $5 \mathrm{~mL}$ of brain heart infusion broth (BHIB; Oxoid, Ltd., Basingstoke, UK). Samples were then incubated overnight $(15 \mathrm{~h})$ in a shaking incubator $(100 \mathrm{rpm})$ at $37^{\circ} \mathrm{C}$. After enrichment, the samples were diluted to an $\mathrm{OD}_{600}$ of 0.01 in $\mathrm{PBS}$ ( $\mathrm{pH}$ 7.4). Samples were tested by our 7-plex microbead-based immunoassay using the Luminex $X M A P \circledR$ technology (q.v.). The STEC strains used in this study were human and environmental isolates including the seven serogroups more commonly associated with outbreak of human illnesses. The serogroups of the strains used were previously confirmed by PCR (Lin et al., 2011). Appropriate Biosafety Level 2 precautions were used when handling pathogenic E. coli organisms.

\subsection{Buffers and reagents}

Phosphate-buffered saline (PBS) with a pH of 7.4 was used to prepare PBS-TB (PBS, $0.02 \%$ Tween 20 , and $1 \%$ bovine serum albumin) and PBS-T (PBS and 0.1\% Tween 20) that were used for washes. Reagent-grade chemicals (i.e., 2,29-azino-bis(3-ethylbenzthiazoline-6-sulfonic acid) [ABTS], $\mathrm{H}_{2} \mathrm{O}_{2}, \mathrm{KCl}, \mathrm{Na}_{3}$ citrate, $\mathrm{NaCl}$, and Tween 20) were purchased from Sigma Chemical Co. (St Louis, MO); immunoglobulin (Ig) G-free, protease-free bovine serum albumin from Jackson ImmunoResearch (West Grove, PA); streptavidin labeled with R-phycoerythrin from Invitrogen (Carlsbad, CA); and streptavidin-horseradish peroxidase conjugate from Zymed (San Francisco, CA).
Table 1

STEC strains tested by the 7-plex microbead-based immunoassay.

\begin{tabular}{|c|c|c|c|c|c|}
\hline $\begin{array}{l}\text { O } \\
\text { serogroup }\end{array}$ & $\begin{array}{l}\text { Strain } \\
\text { identification }\end{array}$ & $\begin{array}{l}\mathrm{O} \\
\text { serogroup }\end{array}$ & $\begin{array}{l}\text { Strain } \\
\text { identification }\end{array}$ & $\begin{array}{l}\mathrm{O} \\
\text { serogroup }\end{array}$ & $\begin{array}{l}\text { Strain } \\
\text { identification }\end{array}$ \\
\hline \multirow[t]{10}{*}{$\mathrm{O} 26$} & $\mathrm{H} 19^{\mathrm{a}}$ & \multirow[t]{15}{*}{0111} & CL-37 ${ }^{\mathrm{a}}$ & \multirow[t]{34}{*}{0157} & $5343^{c}$ \\
\hline & $\mathrm{DEC} 10 \mathrm{~B}^{\mathrm{a}}$ & & $\mathrm{DEC}^{8} \mathrm{~B}^{\mathrm{a}}$ & & $5354^{c}$ \\
\hline & $\mathrm{DEC} 10 \mathrm{C}^{\mathrm{a}}$ & & $3007-85^{a}$ & & $5618^{c}$ \\
\hline & $\mathrm{DEC}^{\mathrm{a}}$ & & TB226A ${ }^{a}$ & & $5718^{\mathrm{c}}$ \\
\hline & TB285C ${ }^{\mathrm{a}}$ & & $928 / 91^{\mathrm{a}}$ & & $6411^{c}$ \\
\hline & VP30 & & $412 / 55^{\mathrm{a}}$ & & $6418^{c}$ \\
\hline & TB285A ${ }^{a}$ & & $\mathrm{DEC}^{\mathrm{a}} \mathrm{C}^{\mathrm{a}}$ & & $6448^{\mathrm{c}}$ \\
\hline & TB352A ${ }^{\mathrm{a}}$ & & $\mathrm{C} 412^{\mathrm{a}}$ & & $6515^{c}$ \\
\hline & EK29 ${ }^{\mathrm{a}}$ & & BCL19a & & $6577^{c}$ \\
\hline & $97-3250^{a}$ & & $\mathrm{ED}-31^{\mathrm{a}}$ & & $6613^{c}$ \\
\hline \multirow[t]{10}{*}{045} & TWO7947 $^{\mathrm{a}}$ & & $\mathrm{BCL}_{17}^{\mathrm{a}}$ & & $6633^{c}$ \\
\hline & $\mathrm{B} 8026-\mathrm{C} 1^{\mathrm{a}}$ & & EK35 & & $6646^{\mathrm{c}}$ \\
\hline & B8227-C8 ${ }^{a}$ & & $3215-99^{a}$ & & \\
\hline & $08-00017^{b}$ & & $D A-18^{a}$ & & \\
\hline & $\mathrm{D} 88-28058^{\mathrm{a}}$ & & $88-4110 \mathrm{H}^{\mathrm{a}}$ & & \\
\hline & $\mathrm{DEC} 11 \mathrm{C}^{\mathrm{a}}$ & \multirow[t]{11}{*}{0121} & DA-69a & & \\
\hline & $5431-72^{\mathrm{a}}$ & & $\mathrm{MT}_{4} 2^{\mathrm{a}}$ & & \\
\hline & $4309-65^{a}$ & & $3-524^{a}$ & & \\
\hline & $2566-58^{a}$ & & F6173 & & \\
\hline & $\mathrm{B} 8227-\mathrm{C}^{\mathrm{a}}$ & & DA- $1^{\mathrm{a}}$ & & \\
\hline \multirow[t]{14}{*}{0103} & TB154A ${ }^{\mathrm{a}}$ & & DA- $5^{\mathrm{a}}$ & & \\
\hline & $87-2931^{a}$ & & $\mathrm{DA}-37^{\mathrm{a}}$ & & \\
\hline & MT\#82a & & $\mathrm{MT} \# 2^{\mathrm{a}}$ & & \\
\hline & MT\#80a & & $87-2914^{a}$ & & \\
\hline & $\mathrm{EK} 30^{\mathrm{a}}$ & & MT\#11 ${ }^{\mathrm{a}}$ & & \\
\hline & $\mathrm{EK} 31^{\mathrm{a}}$ & & $\mathrm{MT} \# 22^{\mathrm{a}}$ & & \\
\hline & $\mathrm{EK} 32^{\mathrm{a}}$ & \multirow[t]{8}{*}{0145} & GS-G5578620 & & \\
\hline & $109-494^{a}$ & & IHIT0304 & & \\
\hline & $107-226^{a}$ & & TB269C ${ }^{\mathrm{a}}$ & & \\
\hline & $\mathrm{PMK}^{\mathrm{a}}$ & & MT\#66 ${ }^{\mathrm{a}}$ & & \\
\hline & RW1372a & & $\mathrm{BCL} 3^{\mathrm{a}}$ & & \\
\hline & RW1374a & & IH $16^{\mathrm{a}}$ & & \\
\hline & $\mathrm{DA} 40^{\mathrm{a}}$ & & $02-3422^{a}$ & & \\
\hline & $\mathrm{D} 55^{\mathrm{a}}$ & & & & \\
\hline
\end{tabular}

a Strains obtained from the STEC center at Michigan State University's National Food Safety and Toxicology Center, East Lansing, MI.

b Strain obtained from the Ohio State Department of Agriculture, Reynoldsburg, $\mathrm{OH}$. c Strains obtained from the Orange County Public Health Laboratory, Santa Ana, CA.

\subsection{Indirect ELISA assay protocol}

A representative strain of each $E$. coli serogroup was diluted to an $\mathrm{OD}_{600}$ of 0.01 in PBS ( $\mathrm{pH}$ 7.4). The wells of a 96-well plate (Nunc, Rochester, NY) were coated with $100 \mu \mathrm{L}$ of the diluted bacteria and incubated overnight at $4{ }^{\circ} \mathrm{C}$. After removing the bacterial solution, the plates were washed three times with PBS-T and blocked with $200 \mu \mathrm{L}$ of PBS-TB for $1 \mathrm{~h}$ at room temperature. After three washes with PBS-T, $100 \mu \mathrm{L}$ of antibody solutions was added to the plate and incubated for $1 \mathrm{~h}$ at room temperature. After three washes with PBS-T, $100 \mu \mathrm{L}$ of a 1/500 dilution of HRP-conjugated goat anti-rabbit, rabbit anti-goat, or rabbit anti-mouse polyclonal was added to each well and incubated for $1 \mathrm{~h}$ at room temperature. After three washes with PBS-T, $100 \mu \mathrm{L}$ of ABTS (2,29-azino-bis(3-ethylbenzthiazoline-6-sulfonic acid; Sigma Chemical Co., St Louis, MO)-horseradish peroxidase substrate solution (Zymed, San Francisco, CA)) was added to each well to detect bound, conjugated antibodies. This substrate solution ( $\mathrm{pH} 4.2$ ) was made of $0.548 \mathrm{~g} / \mathrm{L}$ of ABTS and $17.64 \mathrm{~g} / \mathrm{L}$ of sodium citrate (Sigma Chemical Co.). A total of $40 \mu \mathrm{L}$ of $1 \mathrm{M} \mathrm{H}_{2} \mathrm{O}_{2}$ was then added to $6 \mathrm{~mL}$ of ABTS citrate. After 15 min of incubation at room temperature, absorbance was read at $405 \mathrm{~nm}$ with the Wallac Victor 2 Multilabel Counter (PerkinElmer, Inc., Waltham, MA).

\subsection{Sandwich ELISA assay protocol}

Selected antibodies were previously tested by sandwich ELISA to optimize the assay conditions (i.e., concentrations of capture and detector antibodies) prior to incorporating those into a 7-plex microbead-based immunoassay on the Luminex platform for further specificity testing 
(Bernard et al., 2012). A checkerboard analysis was conducted to assess which concentrations of capture and detector antibodies worked best.

One hundred microliters of a solution in PBS ( $\mathrm{pH} 7.4)$ of capture antibodies (i.e., ranging from 0.5 to $2.0 \mu \mathrm{g} / \mathrm{mL}$ ) was added to each well of a 96-well plate (Nunc, Rochester, NY) and incubated overnight at $4{ }^{\circ} \mathrm{C}$. After removing the capture antibody solution, the plates were then blocked with $200 \mu \mathrm{L}$ of PBS-TB for $1 \mathrm{~h}$ at room temperature. After three washes with PBS-T, $100 \mu \mathrm{L}$ of analyte solutions was added to the plate and incubated for $1 \mathrm{~h}$ at room temperature. After three washes with PBS-T, $100 \mu \mathrm{L}$ of a $0.5-\mathrm{mg} / \mathrm{mL}$ solution in PBS $\mathrm{pH} 7.4$ of detector antibody (i.e., ranging from 0.125 to $2.0 \mu \mathrm{g} / \mathrm{mL}$ ) was added to each well and incubated for $1 \mathrm{~h}$ at room temperature. After three washes with PBS-T, $100 \mu \mathrm{L}$ of a 1/5000 dilution of streptavidin-horseradish peroxidase conjugate in PBS-TB was added to each well and incubated for $1 \mathrm{~h}$ at room temperature. After three washes with PBS-T, $100 \mu \mathrm{L}$ of ABTS-horseradish peroxidase substrate solution was added to each well to detect bound, conjugated antibody. After $15 \mathrm{~min}$ of incubation at room temperature, absorbance was read at $405 \mathrm{~nm}$ with the Wallac Victor 2 Multilabel Counter (PerkinElmer, Inc., Waltham, MA). The optimal antigen, capture, and detector antibody concentrations were determined by serial dilutions. For all the pairs of antibodies tested, using the capture antibodies at a concentration of $1 \mu \mathrm{g} / \mathrm{mL}$ and detector antibodies at a concentration of $0.5 \mu \mathrm{g} / \mathrm{mL}$ worked best (data not shown).

\subsection{Covalent coupling of antibodies to carboxylated magnetic}

Seven different sets of spectrally unique carboxylated Magplex superparamagnetic microbeads $(6.5 \mathrm{~mm}$ in diameter; Luminex Corp., Austin, TX) were coated with capture antibodies according to the manufacturer's instructions provided with the Bio-Plex Amine Coupling Kit (Bio-Rad, Hercules, CA). Bead region numbers 35, 51, 52, 53, 54, 55, and 56 were used to couple the capture antibodies for $0157,026,045$, 0103, 0111, 0121, and 0145, respectively. Briefly, each antibody was covalently coupled to a unique set of microbeads $\left(1.25 \times 10^{6}\right.$ beads per $100 \mu \mathrm{L}$ coupling reaction) in a two-step carbodiimide-coupling protocol that utilized $50 \mathrm{mg} / \mathrm{mL} \mathrm{N}$-hydroxysulfosuccinimide sodium salt (Pierce Chemicals, Rockford, IL) and $50 \mathrm{mg} / \mathrm{mL}$ 1-ethyl-3-(3dimethylaminopropyl) carbodiimide hydrochloride (Pierce Chemicals). After each reaction, the concentration of the microbead suspension was determined by a hemacytometer, and the coupled microbeads stored at 2 to $8{ }^{\circ} \mathrm{C}$ in the dark. Each coupling reaction was confirmed with phycoerythrin-labeled specie anti-species $\operatorname{Ig} G$ antibodies (Invitrogen) at concentrations ranging from 0.5 to $32 \mu \mathrm{g} / \mathrm{mL}$ (Fig. 1).

\subsection{7-Plex microbead-based immunoassay protocol}

The 7-plex microbead-based immunoassays were conducted in black, 96-well round bottom polystyrene microplates (Corning Costar, Lowell, MA), according to Luminex protocols (www.luminexcorp. com). All incubations were for $1 \mathrm{~h}$ at room temperature, protected

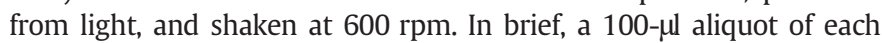
test sample (bacteria diluted in PBS to $\mathrm{OD}_{600} 0.01$ ) was combined with 5000 microbeads (previously blocked for $30 \mathrm{~min}$ in PBS-TB) of each of the seven specificities: E. coli 026, 045, 0103, 0111, 0121, 0145, and 0157 in a single microplate well. The microbeads were washed from unbound reaction components three times with PBS-TB using the BioPlex Pro Wash Station (Bio-Rad). Microbeads were then resuspended in $100 \mu \mathrm{L}$ of the biotinylated detector antibody cocktail, containing $1 \mu \mathrm{g} / \mathrm{mL}$ of each antibody and the resultant mixture was incubated. The mixture was then washed three times as described earlier, resuspended in $100 \mu \mathrm{L}$ of $4 \mu \mathrm{g} / \mathrm{mL}$ streptavidin labeled with $\mathrm{R}$ phycoerythrin, and the resultant mixture was incubated, washed, and resuspended in $100 \mu \mathrm{L}$ of PBS. The samples were analyzed by Bio-Plex Manager 6.0 standard software (Bio-Rad) with the Luminex 100 flow analyzer. Data were acquired using the following settings: $50 \mu \mathrm{L}$ sample volume, 100 beads per region, 120 s reading, and DD gate 5000-25,000.

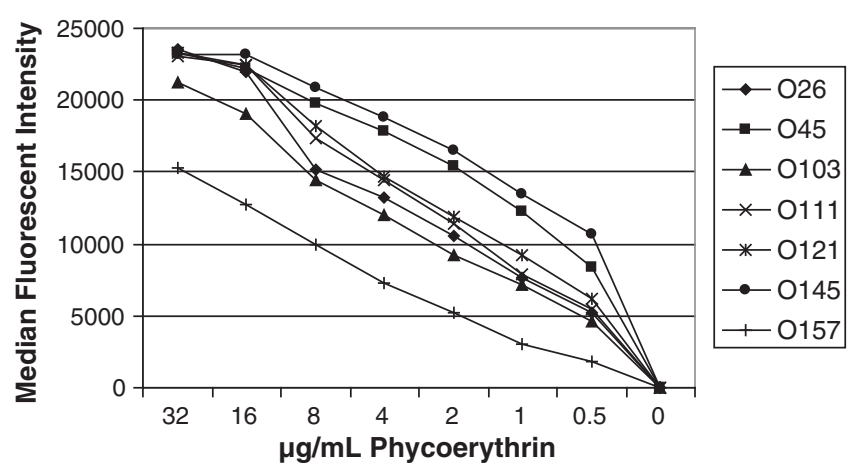

Fig. 1. Confirmation of antibody coupling to the Luminex microbeads using phycoerythrin (PE)-labeled anti-species.

The background fluorescence (i.e., blank samples) was measured on samples containing all immunoassay reagents except the analyte(s) of interest. In fact, every microbead has an inherent fluorescence because of the two fluorochromes embedded in each microbead.

\subsection{Statistical analysis}

For statistical analysis, the threshold for a positive result was defined as a net Median Fluorescent Intensity (MFI) value that was at least three times greater than the background MFI.

\section{Results}

\subsection{Antibody coupling to microbeads}

Once conditions were optimized by sandwich ELISA, the surface area of a microplate well was compared to the surface area of a microbead in order to calculate the amount of capture antibodies necessary for coupling. After coupling we used PE-labeled anti-species antibodies (in a single-plex format) to confirm that the antibodies had been coupled to the microbeads successfully. In this immunoassay, the background wells contained the beads, but not the anti-species-PE (i.e., $\mathrm{MFI}<30$ ). In Fig. 1, the high MFI values, ranging from 15,338 for 0157 to 23,532.5 for 026 , indicated that the antibodies were successfully coupled to the beads.

\subsection{7-Plex microbead-based immunoassay specificity}

The specificity of the 7-plex microbead-based immunoassay was tested by examining 79 STEC strains listed in Table 1, representing the seven $\mathrm{O}$ serogroups included in the assay. The resulting signal to background ratios is shown in Table 2 with positive samples and standard deviations indicated in bold. Except for one strain belonging to the 0111 serogroup (i.e., BCL-19), all others were correctly identified. Thus the recovery of STEC by our newly developed 7-plex microbead-based immunoassay was $98.7 \%$.

\section{Discussion}

A recent study by Verstraete et al. (2012) evaluated a method for the isolation of non-0157 STEC and sorbitol fermenting (SF) E. coli 0157 in food (Possé et al., 2008), where samples were also submitted to a rapid predictive screening test for virulence genes (stx, eae, and ehxA [enterohemolysin]). The non-0157 STEC serotypes studied included 026, 0103, 0111, 0145, non-sorbitol fermenting (NSF) 0157, and SF 0157. Food enrichments (i.e., minced beef, raw-milk cheese, and sprouted seeds) were inoculated with low numbers of bacterial cells of above mentioned serotypes. Bacterial cells were either non-stressed, cold stressed or freeze stressed. Of the analyzed serotypes only 0111 and SF 0157 strains resulted in an increased number of false negatives. 
Table 2

Ranges of the signal to background ratio of O serogroup specific antibodies.

\begin{tabular}{|c|c|c|c|c|c|c|c|}
\hline \multirow[t]{2}{*}{ Target analyte } & \multicolumn{7}{|c|}{ O serogroup specific antibodies } \\
\hline & 026 & 045 & 0103 & 0111 & 0121 & 0145 & 0157 \\
\hline 026 & $26.3-56.6$ & $0.3-0.6$ & $0.6-0.7$ & $0.4-0.5$ & $0.8-1.1$ & $0.5-0.6$ & $0.5-1.0$ \\
\hline 045 & $0.8-1.1$ & 21.8-55.0 & $0.9-1.0$ & $0.9-1.1$ & $0.7-0.9$ & $0.9-1.0$ & $0.8-1.3$ \\
\hline 0103 & $0.2-1.3$ & $0.3-1.0$ & $6.9-54.4$ & $0.3-1.1$ & $0.4-1.0$ & $0.3-1.0$ & $0.5-1.1$ \\
\hline 0111 & $0.9-1.1$ & $0.8-1.1$ & $0.8-1.0$ & $57.5-60.6^{\mathrm{a}}$ & $0.8-1.1$ & $0.9-1.1$ & $0.9-1.1$ \\
\hline 0121 & $0.7-1.2$ & $0.8-1.0$ & $0.5-1.1$ & $0.7-1.1$ & 11.6-51.8 & $0.8-1.1$ & $0.9-1.1$ \\
\hline 0145 & $0.4-0.7$ & $0.3-0.8$ & $0.5-0.7$ & $0.4-0.7$ & $0.7-1.0$ & $3.8-61.8$ & $0.6-0.8$ \\
\hline 0157 & $0.4-0.6$ & $0.3-0.5$ & $0.6-0.8$ & $0.4-0.7$ & $0.9-1.3$ & $0.5-0.8$ & 49.6-53.2 \\
\hline
\end{tabular}

a The strain that could not be correctly identified (MFI $=1.0=$ background) was excluded from the range.

The false negatives could possibly be due to the stressed state of cells. Typically, stressed cells endure a longer lag-phase before exponential growth takes place (Jasson et al., 2007), therefore resulting in decreased growth in broth culture after an overnight incubation. In addition it is possible that certain serotypes grow more efficiently in some broths than others, and selective components may reduce the growth of target strains, as could be the case for 0111 serogroup (Verstraete et al., 2012).

Classification of bacteria is typically done in terms of repeating chains of their O-antigen, capsular composition, and flagella antigens (Hitchcock et al., 1986). An important observation is that serotype classification involves the type, but not the number, of repeating O-antigen units. This allows for a level of enhanced variation within a strain of bacteria (Strauss et al., 2009). Strauss et al. (2009) conducted a study in which 5 E. coli strains that expressed O-antigen were compared to one another in terms of LPS length by atomic force microscopy. The strains compared in this study were E. coli 0113:H4, 0113:H21, 0157:H7, 0157:H12, and 0157:H16. Out of these strains 0113:H21 demonstrated a significantly greater LPS length compared to all other strains while 0157:H7 exhibited the second greatest LPS length. This indicates that O-antigen exhibits great variability, and suggests a means for enhanced attachment of E. coli $\mathrm{O} 113$ and $\mathrm{O} 157$ to human intestinal cells and food surfaces, such as fresh produce (Manges et al., 2001). Such variation also explains why the MFI signals in our assay vary from strain to strain, even among a single serogroup.

Future directions include transferring the assay to the new, portable MagPix system. This would ultimately give us a portable, reproducible, and very sensitive assay that is capable of serotyping the top $7 \mathrm{E}$. coli. We also plan on developing monoclonal antibodies for those targets, and adding more antibodies to our 7-plex microbead-based immunoassay such as E. coli 091, 0104, and 0113 as well as other outer membrane proteins eliciting pathogenicity by adhering bacteria onto intestinal epithelial cells. Ultimately we would like to perform our microbead-based immunoassay on the KingFisher automated high throughput platform and test it in food enrichments.

\section{Disclaimer}

The views presented in this article do not necessarily reflect those of the U.S. Food and Drug Administration.

\section{Acknowledgment}

The authors would like to thank the STEC Center at Michigan State University's National Food Safety and Toxicology Center, East Lansing, MI, the Ohio Department of Agriculture, Reynoldsburg, OH, Atin Datta, U.S. Food and Drug Administration, Center for Food Safety and Nutrition, Laurel, MD, and the Orange County Public Health Laboratory, Santa Ana, CA for generously sharing their bacterial cultures.

The U.S. Department of Agriculture (USDA) prohibits discrimination in all its programs and activities on the basis of race, color, national origin, age, disability, and where applicable, sex, marital status, familial status, parental status, religion, sexual orientation, genetic information, political beliefs, reprisal, or because all or part of an individual's income is derived from any public assistance program. (Not all prohibited bases apply to all programs.) Persons with disabilities who require alternative means for communication of program information (Braille, large print, audiotape, etc.) should contact USDA's TARGET Center at (202) 720-2600 (voice and TDD). To file a complaint of discrimination, write to USDA, Director, Office of Civil Rights, 1400 Independence Avenue, S.W., Washington, D.C. 20250-9410, or call (800) 795-3272 (voice) or (202) 720-6382 (TDD). USDA is an equal opportunity provider and employer.

\section{References}

Anonymous, 1995. Outbreak of acute gastroenteritis attributable to Escherichia coli serotype 0104:H21-Helena, Montana, 1994. Morb. Mortal. Wkly. Rep. 44, 501-503. Atkinson, R., Johnson, G., Root, T., Halse, T., Wroblewski, D., Davies, M., Byrd, A., Long, L., Demma, L., Angulo, F., Bopp, C., Gerner-Smidt, P., Strockbine, N., Greene, K., Swaminathan, B., Griffin, P., Schaffzin, J., Goode, B., 2006. Importance of culture confirmation of Shiga toxin-producing Escherichia coli infection as illustrated by outbreaks of gastroenteritis, New York and North Carolina, 2005. Morb. Mortal. Wkly. Rep. 55, 1042-1045.

Banatvala, N., Debeukelaer, M.M., Griffin, P.M., Barrett, T.J., Greene, K.D., Green, J.H., Wells, J.G., 1996. Shiga-like toxin producing Escherichia coli 0111 and associated hemolyticuremic syndrome: a family outbreak. Pediatr. Infect. Dis. J. 15, 1008-1011.

Bernard IV, C., Clotilde, L.M., Lin, A., Hartman, G.L., Salvador, A., Lauzon, C., Muldoon, M., Lindpaintner, K., Lau, D.K., Carter, J.M., 2012. Microbead-based assays for simultaneous detection of various E. coli serogroups. American Society for Microbiology, Annual Meeting, San Francisco, CA.

Bettelheim, K.A., 2001. Enterohaemorrhagic Escherichia coli 0157:H7: a red herring? J. Med. Microbiol. 50, 201-202.

Bettelheim, K.A., 2007. The non-0157 Shiga-toxigenic (verocytotoxigenic) Escherichia coli; under-rated patho-gens. Crit. Rev. Microbiol. 33, 67-87.

Beutin, L., Jahn, S., Fach, P., 2008. Direct rapid and reliable detection of classical enterohaemorrhagic E. coli (EHEC) from single colonies with the "GeneDisc" realtime PCR system. Bundesinstitut für Risikobewertung. BfR; Federal Institute for Risk Assessment, Berlin.

Bosilevac, J.M., Koohmaraie, M., 2011. Prevalence and characterization of non-0157 Shiga toxin-producing Escherichia coli isolates from commercial ground beef in the United States. Appl. Environ. Microbiol. 77, 2103-2112.

Brooks, J.T., Bergmire-Sweat, D., Kennedy, M., Hendricks, K., Garcia, M., Marengo, L., Wells, J., Ying, M., Bibb, W., Griffin, P.M., Hoekstra, R.M., Friedman, C.R., 2004. Outbreak of Shiga toxin-producing Escherichia coli 0111:H8 infections among attendees of a high school cheerleading camp. Clin. Infect. Dis. 38, 190-198.

Brooks, J.T., Sowers, E.G., Wells, J.G., Greene, K.D., Griffin, P.M., Hoekstra, R.M., Strockbine, N.A., 2005. Non-0157 Shiga toxin-producing Escherichia coli infections in the United States, 1983-2002. J. Infect. Dis. 192, 1422-1429.

Centers for Disease Control and Prevention (CDC), 2012. National Shiga toxin-producing Escherichia coli (STEC) Surveillance Annual Summary, 2008. US Department of Health and Human Services. CDC, Atlanta, Georgia.

Fey, P.D., Wickert, R.S., Rupp, M.E., Safranek, T.J., Hinrichs, S.H., 2000. Prevalence of non-0157:H7 Shiga toxin-producing Escherichia coli in diarrheal stool from Nebraska. Emerg. Infect. Dis. 6, 530-533.

Gyles, C.L., 2006. Shiga toxin-producing Escherichia coli: a review. J. Anim. Sci. 85, 45-62.

Hegde, N.V., Cote, R., Muldoon, M., Lindpainter, K., Jayarao, B.M., Muldoon, M., Lindpaintner, K., Kapur, V., Debroy, C., 2012. Detection of the top six non-0157 Shiga toxin-producing Escherichia coli $\mathrm{O}$ groups by ELISA. Foodborne Pathog. Dis. 9, 1044-1048.

Hitchcock, P.J., Leive, L., Makela, P.H., Rietschel, E.T., Strittmatter, W., Morrison, D.C., 1986. Lipopolysaccharide nomenclature-past, present, and future. J. Bacteriol. 166, 699-705.

Hurd, S., 2007. The Connecticut experience with non-0157 STEC "Seek and ye shall find". Presented at the Public Health Significance of Non-0157 Shiga toxinproducing (STEC), Public Meeting, Arlington, VA, 17 October 2007.

Jasson, V., Uyttendaele, M., Rajkovic, A., Debevere, J., 2007. Establishment of procedures provoking sub-lethal injury of Listeria monocytogenes, Campylobacter jejuni and 
Escherichia coli 0157 to serve method performance testing. Int. J. Food Microbiol. 118, 241-249.

Johnson, K.E., Thorpe, C.M., Sears, C.L., 2006. The emerging clinical importance of non0157 Shiga toxin-producing Escherichia coli. Clin. Infect. Dis. 43, 1587-1595.

Lin, A., Nguyen, L., Lee, T., Clotilde, L.M., Kase, J.A., Son, I., Carter, J.M., Lauzon, C.R., 2011. Rapid O serogroup identification of the ten most clinically relevant STECs by Luminex microbead-based suspension array. J. Microbiol. Methods 87, 105-110.

Machado, J., Grimont, F., Grimont, P.A., 2000. Identification of Escherichia coli flagellar types by restriction of the amplified fliC gene. Res. Microbiol. 151, 535-546.

Manges, A.R., Johnson, J.R., Foxman, B., O'Bryan, T.T., Fullerton, K.E., Riley, L.W., 2001. Widespread distribution of urinary tract infections caused by a multidrugresistant Escherichia coli clonal group. N. Engl. J. Med. 345, 1007-1013.

Nataro, J.P., Kaper, J.B., 1998. Diarrheagenic E. coli. Clin. Microbiol. Rev. 11, 142-201.

Olsson-Allen, A.C., Xu, Y., Onisk, D., Muldoon, M., 2011. Development of non-0157 Shiga toxin-producing E. coli (STEC) O-type specific antibodies and their application for the analysis of raw beef. Int. Assoc. Food Protection 2011 Annual Mtg. Milwaukee, WI. July 31-August 3, 2011.

Possé, B., De Zutter, L., Heyndrickx, M., Herman, L., 2008. Quantitative isolation efficiency of 026, 0103, 0111, 0145 and 0157 STEC serotypes from artificially contaminated food and cattle faeces samples using a new isolation protocol. J. Appl. Microbiol. $105,227-235$

Scallan, E., Hoekstra, R.M., Angulo, F.J., Tauxe, R.V., Widdowson, M.A., Roy, S.L., Jones J.L., Griffin, P.M., 2011. Foodborne illness acquired in the United States-major pathogens. Emerg. Infect. Dis. 17 (1), 7-15.

Strauss, J., Burnham, N.A., Camesano, T.A., 2009. Atomic force microscopy study of the role of LPS O-antigen on adhesion of E.coli. J. Mol. Recognit. 22, 347-355.

Tarr, P. Fouser, L.S., Stapleton, A.E., Wilson, R.A., Kim, H.H., Vary Jr., J.C., Clausen, C.R 1996. Hemolytic-uremic syndrome in a six-year-old girl after a urinary tract infection with Shiga-toxin producing Escherichia coli 0103:H2. N. Engl. J. Med. 335, 635-638.

Verstraete, K., Robyn, J., Del-Favero, J., De Rijk, P., Joris, M.A., Herman, L., Heyndrickx, M., De Zutter, L., De Reu, K., 2012. Evaluation of a multiplex-PCR detection in combination with an isolation method for STEC 026, 0103, 0111, 0145 and sorbitol fermenting 0157 in food. Food Microbiol. 29, 49-55.

Willshaw, G.A., Cheasty, T. Smith, H.R, 2000. In: Lund, B.M., Baird-Parker, T.C., Gould, G.W. (Eds.), Escherichia Coli. : The Microbiological Safety and Quality of Food, 2. Aspen Publishers, Gaithersburg, MD, pp. 1136-1177. 